\title{
Memahami Peningkatan Kehadiran China di Pasifik Selatan: Perspektif Realisme Stratejik
}

\author{
Vinsensio M.A. Dugis \\ Departemen Hubungan Internasional, FISIP \\ Universitas Airlangga, Surabaya
}

\begin{abstract}
ABSTRAK
Meningkatnya kehadiran China di Pasifik Selatan menarik perhatian. Peningkatannya di kawasan yang dianggap sebagai 'western lake', secara ekonomi tidak prospektif dan secara politis tidak stabil, telah menimbulkan berbagai pertanyaan. Benarkah sementara Barat menggunakan hard power, China menarik perhatian dengan soft powernya? Peningkatan kehadiran China menimbulkan spekulasi bahwa China adalah hegemon baru. Penulis berargumen bahwa Pasifik Selatan bukan pusat perhatian baru bagi China, dan China bukanlah pemain baru di sana. China adalah aktor global dengan agenda strategis yang dibangunnya di masa lalu dan diperkuatnya ketika wilayah ini ditinggalkan kekuatan-kekuatan tradisionalnya. Menggunakan perspektif realisme stratejik, kehadiran China di Pasifik adalah menyiasatai pluralitas global dalam rangka mengambil peluang strategis. perspektif ini memberi nuansa baru dalam memahami hubungan internasional di Pasifik Selatan.
\end{abstract}

Kata-kata kunci: China, Pasifik Selatan, pluralitas global, realisme stratejik, strategi

Increasing China's presence in the South Pacific have captured attention from many parties. Its increasing presence to the region that has for decades been dubbed as 'western lake', a region economically 'has no future' and politically unstable, has posed many questions. Whilst western powers exercised hard power are South Pacific nations more receptive to China's soft power? China's presence often leads to speculation that China is indeed a new hegemon. The author argues that the South Pacific is not a new area of focus for China, and China is not a new player. China is a global player. It has strategic agendas built in the past and restrengthened when the traditional powers to abandon the region. Using the logic of strategic realism, China's presence in the South Pacific is an effort to manage global plurality as part of its global strategy to gain strategic opportunities of the region. This provided a new perspective in understanding international relations in the South Pacific.

Keywords: China, South Pacific, global plurality, strategic realism, strategy 
Bukti-bukti peningkatan kehadiran dan berbagai manuver diplomasi China di Pasifik Selatan di dalam satu dekade terakhir menimbulkan berbagai macam dugaan, baik positif maupun negatif. Benarkah China memiliki intensi menjadi hegemon baru di Pasifik Selatan? Pertanyaan demikian wajar adanya mengingat China sudah menjalin hubungan dengan negara-negara di wilayah ini sejak era Perang Dingin melalui berbagai bantuan keuangan dan perdagangan. Kehadiran dan interaksi China di Pasifik Selatan tidak hanya melibatkan negara-negara berkembang, tetapi juga dengan negara-negara metropolitan di kawasan itu. Terdapat indikasi yang kuat, bahwa sejak tahun 1980an melalui negara-negara metropolitan ini, kubu Barat memberikan ruang kehadiran kepada China di kawasan dan berperan sebagai faktor penyeimbang kehadiran Uni Soviet. Kesan yang terbentuk ialah peran dan kehadiran China di kawasan ini 'dikehendaki'. Perdana Menteri New Zealand, Robert Muldoon menyampaikan kepada Deng Xiaoping bahwa, 'any support China could give to the island states of the [Pacific] Forum whether political or economic would help maintain political stability in the South Pacific' (Brady 2008, 11). Selanjutnya, adalah Australia, negara Barat pertama yang ketika itu di bawah kepemimpinan Perdana Menteri Gough Whitlam, yang menjalin hubungan diplomatik dengan 'rezim komunis' Beijing, sehingga PM Whitlam sisebut sebagai 'the father of Australia-China Relations' (McDonnell 2014). Selama Perang Dingin berlangsung, New Zealand dan China menjalin hubungan diplomatik yang intensif dan saling menguntungkan, walaupun hubungan-hubungan itu tidak meninggalkan warna dasar ideologis masing-masing.

Seiring dengan berjalannya waktu, perhatian China ke Pasifik Selatan semakin meningkat dan intensif. Hal ini ditandai dengan meningkatnya bantuan ekonomi China kepada negara-negara yang menjalin hubungan diplomatik dengannya. China, yang tercatat sebagai pendonor peringkat ketiga setelah Australia dan AS, juga menawarkan berbagai paket bantuan keuangan yang bertujuan untuk memperkuat perdagangan, membangun infrastruktur, meningkatkan kemampuan pemerintah dan militer, serta mengembangkan sumberdaya alam (Shie 2007, 309). Bantuan ekonomi yang tidak mengikat dengan syarat lunak (Yang 2009, 139) merupakan daya tarik utama bagi negara-negara Pasifik Selatan yang pada umumnya berpenghasilan nasional di bawah rata-rata. Keadaan ini membuat China menjelma menjadi "banker baru" di kawasan, Pasifik Selatan sebagaimana tergambar dalam judul tulisan Fifita dan Hanson (2011) "China in the Pacific: The New Banker in Town". Disamping dengan instrumen bantuan ekonomi, intensitas kehadiran China juga ditopang dengan diplomasi kultural, seperti pendirian sekolah hukum di University of the South Pacific di Suva (ibukota Fiji), pertukaran pelajar, dan pengajaran Bahasa Mandarin di stasiun televisi lokal. 
Diplomasi China disambut baik oleh para pemimpin negara-negara Pasifik, selain karena 'kemurahan hati'nya, status China sebagai sesama negara berkembang sangat membantu penerimaan kehadirannya di kawasan ini. Sudah cukup lama Beijing menjadi ibukota negara asing pertama yang dikunjungi oleh para pemimpin Pasifik yang baru dilantik. Kunjungan pemimpin Fiji, Vanuatu, PNG, Samoa, Federated States of Micronesia, Tonga dan Kiribati menunjukkan bahwa para pemimpin ini lebih banyak menaruh harapan pada China daripada ke AS, Australia maupun New Zealand (Henderson \& Reilly 2003, 95). Kedatangan PM Wen Jiabao pada pertemuan PIF pada April 2006 dan penandatanganan paket bantuan sejumlah US $\$ 374$ juta memberi kesempatan China bermain lebih leluasa (Yang 2009, 140).

Ditinjau dari sejarah kehadirannya, berbagai aktivitas China di kawasan Pasifik Selatan, termasuk peningkatan kehadiran yang diperlihatkan setidaknya satu dekade belakangan ini, sesungguhnya bukanlah merupakan hal yang asing bagi sebagian besar negara di Pasifik Selatan. Sekali pun demikian, hal itu mengundang reaksi yang tidak proporsional dari beberapa negara besar yang merupakan aktor tradisional di wilayah itu, seperti Amerika Serikat, Perancis, Australia dan Selandia Baru (Hayward-Jones 2013; Lum \& Vaughn 2007). Hubungan China yang semakin intensif setelah berakhirnya Perang Dingin memunculkan sejumlah dugaan yang sebagian besar cenderung mengkhawatirkan perkembangan tersebut. Hegarty (2015) secara ekplisit berpendapat bahwa kehadiran China di kawasan Pasifik Selatan jelas-jelas telah mengurangi peran tradisional dan posisi kepemimpinan Australia di kawasan ini. Dugaan seperti ini mencerminkan masih kuatnya kekhawatiran banyak pihak pada sifat agresif China di masa lalu. Sekretaris Parlemen Australia untuk Urusan Kepulauan Pasifik (Australian's Parliamentary Secretary for Pacific Islands Affairs), Ricahrad Marsles, tahun 2012 juga secara terbuka mengatakan bahwa peningkatan kehadiran militer China di Pasifik Selatan boleh jadi membawa ancaman bagi Australia (Wallis 2012). Sementara itu, kehadiran Menteri Luar Negeri AS, Hillary Clinton di pertemuan Pacific Islands Forum (PIF) pada bulan Agustus 2012 mengindikasikan adanya kekhawatiran dimaksud (Wallis 2012).

\section{Threat Theory \& Realisme Stratejik}

Dalam hubungan antar negara, persepsi berperan penting dalam membentuk politik luar negeri. Persepsi ancaman merupakan salah satu faktor penting yang dipertimbangkan oleh pembuat keputusan luar negeri, bahkan jauh lebih penting dari ancaman itu sendiri. Kemunculan (kembali) China sebagai salah satu kekuatan penting dunia di tatanan 
dunia baru menjadi perhatian banyak kalangan, baik akademisi maupun praktisi. Kehadiran China menimbulkan respon yang berbeda-beda, mulai yang bersifat 'pesimis', seperti kecemburuan, kehati-hatian, kecurigaan, penolakan, sampai yang 'optimis', yaitu kekaguman (Bustelo 2005). Secara umum, mengamati kemunculan kembali China dirangkum dalam perdebatan "China threat theory" (zhongguo weixie lun)', yang meliputi ancaman militer, ekonomi dan kultural-ideologi. Persaingan ideologi antara AS dan Uni Soviet menguntungkan China karena negara ini memanfaatkan lingkungan internasional yang stabil dengan menerapkan kebijakan modernisasi dan pintu terbuka. Politik ini berhasil membawa China pada keberhasilan pembangunan ekonomi dan pengembangan kapabiltas militer. Perkembangan China yang luar biasa dan perannya yang lebih asertif menyebabkan negara ini dianggap sebagai ancaman keamanan di Asia Timur.

Logika "China threat theory" hampir sepenuhnya mirip dengan penjelasan perspektif offensive realism. Menurut perspektif ini, sifat anarki sistem internasional pada hakekatnya mendorong munculnya kecenderungan ekspasif-agresif negara-negara atau keterlibatan bertahan secara selektif (defensive selective engagement), dan cara-cara ini dianggap sebagai jalan terbaik mendapatkan keamanan. Sistem internasional cenderung menciptakan strategi yang ofensif sebab anarki menghadirkan ketidakamanan, dan oleh karenanya maka superioritas dalam hal kapabilitas, terutama militer, memberi jaminan terhadap kesuksesan (Mearsheimer 2001). Selanjutnya Mearsheimer (2004) juga menulis, pada dasarnya negara memiliki rasa takut terhadap satu sama lain sehingga setiap negara memiliki niat menyerang negara lain dengan kapabilitas menyerang yang dimilikinya. Sifat anarkis memperburuk ketakutan ini, sehingga cara terbaik untuk bertahan adalah menjadi 'as powerful as possible relative to potential rivals'. Semakin kuat negara, semakin kecil kemungkinan unuk diserang dan tujuan akhir negara adalah menjadi hegemon dan great power tunggal.

Logika berpikir offensive realism ini tentu sejalan dengan "China threat theory" di atas. China diprediksikan akan mendominasi Asia seperti AS mendominasi Dunia Barat. China akan berusaha semaksimal mungkin menutup kesenjangan kekuasaan antara dirinya dan tetangganya, terutama Jepang dan Rusia karena China harus memastikan bahwa

\footnotetext{
1 Istilah "China threat theory" merujuk pada sejumlah literatur yang melihat kemunculan China sebagai ancaman bagi negara lain. Terdapat beberapa sebutan negatif untuk menggambarkan China, di antaranya "clash of civilization", "China collapse theory", "yellow peril theory", "contain China", dan sebagainya, yang secara keseluruhan dilabeli sebagai "China threat theory". Bagi pemerintah dan rakyat China, teori ini merupakan ancaman, yang dipercaya sebagian besar diproduksi oleh media, sarjana, dan politisi yang menunjukkan sikap tidak bersahabat dengan China. Teori ini dapat mengganggu hubungan China dengan negara-negara tetangganya dan AS (Chengqiu Wu 1999, 111).
} 
tidak ada negara di Asia yang memiliki sarana untuk mengancam dirinya. Kehadiran China di Pasifik Selatan adalah cermin dari hasrat hegemon yang ingin menambah superioritasnya ke tingkat global. Tetapi problemnya adalah, hampir tidak ada great power yang dengan suka rela melihat kemunculan great power lainnya. Great power akan melakukan tindakan apa pun untuk menghalagi munculnya great power baru yang akan menggantikannya. Dengan demikian, ujung dari peningkatan kehadiran China di Pasifik Selatan kemungkinan membuat hegemon lama, dalam hal ini AS, merespons dengan meningkatkan kehadirannya, termasuk dengan cara mengajak dan mendorong sekutusekutu lama AS yang secara tradisional mempunyai peran di kawasn ini, Australia dan New Zealand, akan melakukan reposisi perana kepemimpinan di kawasan Pasifik Selatan sebagai respons atas kehadiran China.

Berbeda dengan potret kehadiran China sebagaimana tergambar di atas, kaum neorealis dengan pendekatan strukturalnya, cenderung bernuansa defensif (defensive realism) di dalam melihat fenomena yang ada. Perspektif ini cenderung percaya bahwa keseimbangan power akan selalu terjadi dalam sistem internasional karena unipolaritas tidak akan bertahan lama. Kenneth Waltz $(2000,28)$ mengemukakan dua alasan. Pertama, kekuatan dominan yang cenderung mengambil alih terlalu banyak tanggungjawab di luar kemampuannya sendiri, dapat memperlemah kekuatannya dalam jangka panjang. Kedua, sekalipun kekuatan dominan bertindak hati-hati, moderasi, dan menahan diri, negara lemah akan selalu mengkhawatirkan perilaku negara dominan di masa datang. Tidak seperti era sebelumnya, terjadi vacuum of power di masa pasca Perang Dingin, sehingga, terjadi ketidakseimbangan kekuatan (unbalanced power). Di dalam menghadapi situasi ini, maka sebagian negara mencoba meningkatkan kapasitas masing-masing atau bersekutu dengan negara-negara lain sehingga perimbangan kekuatan global kembali tercapai (Waltz 2000, 28).

Mengikuti logika perspektif defensive realism ini sulit rasanya China dilihat sebagai ancaman baru. Menjadi hegemon tidak semata-mata hanya diperhitungkan dari kapasitasnya untuk mendominasi karena biaya dan resiko untuk menjadi hegemon amat tinggi seperti yang dikatakan John Mearsheimer (1990, 13), hegemony is rare because 'the costs of expansion usually outrun the benefits before domination is achieved'. Mempertimbangkan menguat dan dominannya peran China di Pasifik Selatan, menjadi pertanyaan penting apakah China akan menggantikan AS sebagai hegemon di kawasan ini? Beban jangka panjang sebagai global hegemon dan konsekuansi jangka panjang dari tanggungjawab tersebut nampaknya menjadi pertimbangan besar bagi para pemimpin China untuk tidak mengambil peran itu. Di dalam berbagai kesempatan, sebagaimana dikupas juga pada bagian-bagian 
berikut dari tulisan ini, para pemimpin China berkali-kali mengatakan bahwa China tidak mempunyai kehendak untuk menjadi kekuatan hegemon. Disamping itu, perimbangan kekuatan terhadap kehadiran China di kawasan Pasifik Selatan setidaknya akan datang dari Australia dan Selandia Baru yang secara tradisional menganggap kawasan Pasifik Selatan sebagai kawasan "halaman belakang" keduanya. Dengan begitu, kehadiran China di kawasan ini hanya akan menaikkan nilai strategis kawasan Pasifik Selatan sebagai "Bazaar Politik". Kehadiran China akan mendorong kekuatan-kekuatan tradisional kembali memberi perhatian lebih ke kawasan halaman belakangnya sehingga. Ujungnya bukanlah persaingan yang sifatnya zero-sum tetapi keuntungan timbal-balik antara negara-negara di kawasan ini dengan China serta Australia dan New Zealand (Hill 2010).

Bereda dengan perspektif-perspektif sebelumnya yang menggunakan pendekatan struktural dalam memandang kemunculan China, dalam pandangan kaum liberal-institusional, tumbuhnya China sebagai kekuatan besar tidak bisa dilepaskan dari faktor domestik, kultural dan historis yang membentuk politik luar negeri China. Pendekatan ini menyediakan salah satu perspektif alternatif dalam melihat ancaman China. Perkembangan militer China yang sangat pesat seiring dengan perkembangan ekonominya, diproyeksikan akan menjadi ancaman bagi Asia Timur yang akan mengerakkan AS sebagai sekutu Korea dan Jepang. Sebagai kekuatan ekonomi, China menguasai pasar global tidak hanya dalam kapasitasnya sebagai pengekspor berbagai kebutuhan sehari-hari yang membanjiri pasar global, tetapi kemampuan teknologinya mampu menyaingi Jepang dan AS. Berdasarkan hal ini, negara-negara lain, terutama AS, mencoba melihat kemunculan kembali China dengan sikap hati-hati, waspada dan mencoba memposisikan munculnya kembali China dalam 'peaceful rise'. Menginterpretasi China dalam posisi demikian tidak bisa dilepaskan dari terbitnya Buku Putih yang berjudul "China's Peaceful Development Road". ${ }^{2}$ Namun demikian, problemnya melihat kehadiran China di Pasifik Selatan dengan perspektif liberal-insitusional ialah logikanya cukup hanya untuk melihat China dalam fenomena ini. Artinya kita menafikan konsistennya sifat agresif China dalam kasus-kasus lain seperti misalnya kehadiran dan klaim-klaimnya di Laut China Selatan.

\footnotetext{
${ }^{2}$ Buku Putih berjudul China's Peaceful Development Road yang terbit pada thun 2005 memuat lima bab, yaitu Pembangunan yang menekankan pada perdamaian (Peaceful Development) merupakan hal yang tidak terhindarkan dari Modernisasi China; Memajukan Perdamaian Dunia dan Pembangunan dengan Perkembangan China secara mandiri; Pembangunan dengan Kemandirian, Reformasi dan Inovasi; Menjalin Kerjasama Saling Menguntungkan dan Pembangunan Bersama dengan Negara-negara Lain; dan Membangun Dunia yang Harmonis di atas Perdamaian Dunia dan kemakmuran Bersama (http://www.china.org.cn/english/2005/Dec/152669.htm).
} 
Uraian-uraian menggunakan perspektif-perspektif di atas jelas terlihat kekurangannya. Oleh karena itu, penulis mencoba meminjam logikalogika dasar strategi global yang diperkenalkan Pankaj Ghemawat (2007). Ia menolak dalil-dalil globalisasi yang overstated dan mengatakan sesungguhnya yang terjadi saat ini adalah semiglobalisasi dimana dunia global masih jauh dari 'unifikasi' sebagaimana tersirat dari ungkapan the flat-world atau global village; berbagai perbedaan masih menjadi warna utama kehidupan global. Strategi utama menghadapi perbedaan-perbedaan ini adalah kapasitas memanage perbedaan dengan cara malakukan adaptasi, agregasi atau arbitrase atau yang disebut "Triple A Strategy". Keberhasilan atau survival bisa terwujud ketika masing-masing A dapat dimainkan dengan sukses; A1 melakukan adaptasi terhadap perbedaan, A2 mengatasi perbedaan, A3 mengeksploitasi perbedaan. Nilai lebih (value creation) dari kesuksesan tercapai ketika masing-masing unsur A ini dapat dikombinasikan dengan baik (Ghemawat 2007).

Dalil-dalil strategi global Ghemawat ini di dalam percaturan hubungan global penulis menyebutnya sebagai 'realisme stratejik' (strategic realism). Struktur sistem internasional pasca Perang Dingin bersifat multipolar yang diwarnai oleh berbagai macam perbedaan. Power tidak lagi semata-mata diukur dari indikator-indikator tradisional. Unsurunsur non-tangible dalam elemen-elemen kekuatan nasional semakin kompleks, belum lagi ketika kekuatan-kekuatan korporasi dan aktoraktor trasnational capitalist class lainya diperhitungkan. Struktur sistem internasional lebih merupakan hasil percaturan interaksi berbagai aktor kekuatan global (state dan non-state) yang oleh Keane (2002) struktur sistem ini disebut dengan "cosmocracy", bentuk komunitas politik global yang ditandai oleh " a complex melange of linked netwokrs of legal, governmental, law enforcement and military interdependence worldwide" (Keane 2002, 65). Karakter yang dominan terlihat dari struktur sistem global ini adalah pluralitas global. Oleh karena itu, elemen utama yang dipercayai oleh pandangan realisme stratejik ini adalah kecenderungan tak terhindarkan negara untuk mencari berbagai cara di dalam menghadapi pluralitas global. Semakin besar kapasitas yang dimiliki suatu negara, maka semakin besar pula peluang dan kecenderungan negara tersebut menggunakan kombinasi ketiga strategi A di atas untuk menghasilkan nilai lebih di dalam interaksi global dengan negara dan aktor-aktor lainnya.

Dengan memakai dalil-dalil perspektif strategic realism ini, penulis berargumen bahwa peningkatan kehadiran China di kawasan Pasifik Selatan tak lebih dari bagian strategi global China di era cosmocracy untuk menyiasati berbagai peluang strategis yang ada di kawasan Pasifik Selatan. Peningkatan kehadiran ini merupakan kelanjutan perubahan politik luar negerinya yang diperlihatkan China semenjak berakhirnya 
Perang Dingin. Kehadiran ini juga memperhitungkan berbagai taruhan termasuk kepentingan-kepentingan lain yang menjadi konsiderasi China.

\section{China pada Pasca Perang Dingin}

Politik luar negeri China pada tahun 1990-an memperlihatkan perilaku yang berbeda dari masa sebelumnya. Memasuki abad ke 21, China lebih banyak menjalankan politik luar negeri yang moderat, yang digambarkan dalam "new grand strategy" atau "security diplomacy" yang dirancang untuk menciptakan kesan positif China dan menunjukkan bahwa negara ini merupakan aktor yang bertanggungjawab dalam sistem internasional yang didominasi oleh AS. Kesan positif ini dibangun melalui penguatan strategi soft power (Severson 2012, 1) yang diimplementasikan dalam berbagai agenda politik luar negeri, seperti kultural, kelembagaan dan bantuan asing. Melalui strategi baru ini, China memperluas hubungan luar negerinya dan berharap semua pihak dapat menerimanya, melupakan kesan negatif yang menggambarkan China sebagai negara yang agresif. Perubahan strategi China disampaikan oleh para pemimpinnya di berbagai forum. Sebagai contoh, menandai peringatan hari lahir Mao Zedong ke 110 pada tahun 2004, Sekretaris Jendral Partai Komunis China, Hu Jintao menyatakan bahwa China seharusnya

"adhere to the development road of peaceful rise, persist in getting along friendly with various countries on the basis of the 'Five Principles of Peaceful Coexistence', actively conduct exchanges and cooperation with other countries based on equality and mutual benefits and make contribution to the lofty cause of peace and development of mankind" (http://www.chinadaily.com.cn/english/doc/200402/20/content_307915.htm).

Pada kesempatan yang berbeda, Pidato Presiden $\mathrm{Hu}$ Jintao pada tahun 2007, di depan kongres Partai Komunis China menegaskan komitmen pentingnya soft power dengan menyatakan,

In the present era, culture has become a more and more important source of national cohesion and creativity and a factor of growing significance in the competition in overall national strength, and the Chinese people have an increasingly ardent desire for a richer cultural life. We must keep to the orientation of advanced socialist culture, bring about a new upsurge in socialist cultural development, stimulate the cultural creativity of the whole nation, and enhance culture as part of the soft power of our country... (President Hu Jintao, 2007). 
Pidato tersebut menandai perubahan mendasar pelaksanaan politik luar negeri China yang menekankan pentingnya pelaksanaan hubungan diplomatik yang harmonis sehingga dapat mendukung pembangunan nasional China. Tekad China untuk memproyeksikan soft power yang merupakan bagian penting bagi diplomasi barunya, merupakan tantangan besar bagi pemerintah China. Strategi politik luar negeri baru ini menuntut China berperan lebih aktif dan bertanggungjawab agar China mampu memperbaiki image-nya di dunia internasional. Sekali pun demikian, tantangan terbesar implementasi strategi baru diplomasi China berasal dari politik domestiknya yang belum sepenuhnya mendukung keberhasilan strategi itu, seperti masih meluasnya korupsi dan lebarnya jurang ketimpangan sosial dan ekonomi. Selain itu perubahan dalam struktur internasional juga belum sepenuhnya mendukung proyeksi China untuk keberhasilan strategi soft power-nya. Keterlibatan China dalam konflik di Laut China Selatan, dan kecenderungan memanasnya situasi politik di Asia Timur dengan ketegangan antara Korea Utara-Korea Selatan bisa menjadi pemicu bagi Beijing untuk melakukan tindakan militer.

\section{Taruhan China di Pasifik Selatan}

Mengapa China tertarik pada Pasifik Selatan? Meskipun kecil dalam luas geografis, jumlah penduduk dan potensi ekonomi, wilayah ini tidak luput dari perhatian China. Seperti telah dinyatakan di atas bahwa China bukanlah sepenuhnya pemain baru di Pasifik Selatan. Imigran China sudah menginjakkan kaki di Pasifik Selatan sejak akhir abad kesembilan belas, bahkan jauh sebelum masa itu. Seperti yang dinyatakan Crocombe (2007) bahwa orang-orang Austronesians yang merupakan cikal bakal bangsa China mendarat di Pasifik sekitar 10.000 tahun silam. Mereka kemudian bermigrasi ke berbagai tempat sehingga ketersebarannya meliputi banyak tempat di Pasifik Selatan. Terdapat sejumlah keturunan China yang menetap di sub-wilayah Melanesia (Solomon Islands, Vanuatu, dan New Caledonia), Micronesia (Kiribati, Nauru, Tonga, Cook Islands). Mereka dikategorikan menjadi empat tipe, yakni huashang (pedagang), huagong (buruh kontrak), huaqiao (pendatang), dan huayi (keturunan China yang tidak lagi memiliki keterikatan dengan tanah leluhurnya) (Willmott 2007).

Setelah menjadi negara merdeka, China juga menjalin hubungan diplomatik dengan Fiji sesegera setelah kemerdekaan Fiji pada tahun 1970. Kehadiran China semakin intensif karena didorong oleh persaingannya dengan Uni Soviet yang mulai menaruh perhatian pada Pasifik Selatan pada tahun 1980-an. Untuk menambah intensitas keterlibatannya di Pasifik, China hadir sebagai peninjau dalam Pacific Island Forum dan secara formal maupun informal China 
mempertahankan hubungan baik dengan negara-negara di Pasifik. Para pemimpin Pasifik Selatan juga melakukan kunjungan secara teratur ke Beijing (Wesley-Smith 2007, 2). Selain itu China juga aktif menjadi pengamat dalam Melanesian Spearhead Group (MSG), memberi bantuan pembangunan infrastruktur dan bantuan pembangunan lainnya di negara-negara MSG, organisasi yang terdiri dari negaranegara ras Melanesia, yaitu PNG, Fiji, Solomon Islands, Vanuatu dan "pesaing" PIF. Dalam beberapa hal bahkan China lebih berperan dominan di MSG daripada PIF karena MSG tidak melibatkan Ausralia dan New Zealand (Brady 2015).

Sekali pun demikian, China juga bukanlah pemain tradisional di wilayah itu. Sejak berakhirnya Perang Dingin, China meningkatkan perhatiannya di kawasan ini, bukan karena vacuum of power, namun justru karena meningkatnya perhatian dan kehadiran kembali negara-negara Barat seperti Australia, New Zealand, Prancis, Uni Eropa dan Jepang (WesleySmith 2007, 2). China menjalin hubungan diplomatik dengan Cook Islands, the Federated States of Micronesia (FSM), Fiji, Niue, Papua New Guinea (PNG), Samoa, Tonga dan Vanuatu. Perhatian China ditunjukkan dengan pemberian bantuan keuangan kepada negaranegara tersebut, dan China tercatat sebagai negara donor dengan jumlah bantuan yang cukup signifikan. Sebagai wilayah yang terdiri dari banyak negara berkembang dengan rata-rata penghasilan nasional yang rendah, kehadiran China disambut dengan tangan terbuka oleh para pemimpin negara-negara Pasifik di satu fihak, namun menjadi sumber ancaman bagi negara-negara pemain tradisional, di fihak lain. Apakah yang menjadi taruhan China di Pasifik Selatan, di sebuah wilayah yang dikenal sebagai western lake?

Dominasi Barat menjadi salah satu unsur penting yang menandai hubungan internasional di Pasifik Selatan. Kuatnya dominasi ini ditunjukkan dengan beberapa indikator. Pertama, negara-negara barat merupakan kekuatan kolonial di Pasifik: AS, Inggris, Prancis, Australia, dan New Zealand. Setelah merdeka sistem politik negara-negara baru tersebut adalah demokrasi liberal, setidaknya secara prosedural. Kedua, sebutan Pasifik sebagai "Danau (bagi negara-negara) Barat" nampak dari bantuan keuangan yang diterima dari negara-negara mantan kekuatan kolonialnya. Setidaknya sampai dengan pertengahan tahun 1990-an kekuatan-kekuatan kolonial masih secara intensif menjangkarkan pengaruhnya di sana. Bahkan setelah proses dekolonisasi, beberapa wilayah masih secara resmi menjadi daerah kekuasaan negara-negara Barat, seperti Cook Islands, Tokelau dan Nieu (di bawah kekuasaan New Zealand), American Samoa, Guam, Northern Mariana Islands (di bawah kekuasaan AS), New Caledonia, French Polynesia, Wallis and Futuna (di bawah kekuasaan Prancis). Ketiga, beberapa wilayah masih menjadi pangkalan militer AS (Northern 
Mariana Islands, FAS, Republic of Marshall Islands, FSM, Palau American Samoa dan Guam). AS juga bekerjasama dengan Australia dan New Zealand untuk menempatkan pasukannya di sekitar perairan Samudra Pasifik. Ketiga, ideologi Kristiani yang dibawa oleh negaranegara kolonial menjadi agama yang dominan di Pasifik Selatan dan sekaligus menandai sentimen anti-komunis yang kuat.

Selain dikenal sebagai 'western lake' Pasifik Selatan merupakan wilayah yang tidak stabil secara politik. Perkembangan geopolitik di Pasifik Selatan diwarnai oleh berbagai gejolak internal. Istilah 'the arc of instability' wilayah ini diwarnai oleh berbagai peristiwa instabilitas, mulai dari kudeta dan pertikaian ras (di Fiji), pertikaian kelompok etnis dan low level intensity conflict (di Solomon, PNG, New Caledonia), lemahnya penegakan hukum dan tatanan di hampir seluruh negara, tingginya tingkat kriminalitas lintas negara, seperti pencucian uang, penyelundupan dan perdagangan manusia, perdagangan obat terlarang dan senjata kecil, pencurian kekayaan laut, dan sebagainya. Secara normal, status Pasifik Selatan sebagai the arc of instability membuat sebagian negara enggan berinteraksi dengannya, namun China melakukan hal yang sebaliknya. Dalam beberapa hal, China memanfaatkan, bahkan menjadi salah satu faktor penyebab terciptanya status tersebut. Australia dan New Zealand secara tidak langsung mengundang kehadiran intensif China di Pasifik. Penetrasi China semakin meningkat setelah Australia dan New Zealand mengisolasi Fiji setelah kudeta tahun 2006. Pemerintah Suva merespon isolasi tersebut dengan mengadopsi politik luar negeri 'look north', dengan mendekatkan diri pada China. Sikap Australia dan New Zealand yang membekukan keanggotaan Fiji di Pacific Island Forum (PIF) membuka peluang bagi China untuk lebih dekat dengan Melanesian Spearhead Group (MSG) 3 yang merupakan 'pesaing' bagi PIF. China menjadi pendukung utama MSG, kelompok eksklusif di Pasifik Selatan tanpa keterlibatan Australia dan New Zealand.

\section{Prioritas China \& 'Chequebook Diplomacy'}

Agenda-agenda diplomasi China yang menampakkan image baru China yang damai, seperti yang dinyatakan oleh para elit China bagi sebagian fihak dapat diterima sebagai sebuah kenyataan, sekali pun tetap menyisakan pesimisme bagi pihak lain. AS sebagai hegemon di Pasifik telah menetapkan bahwa tahun 2007 adalah 'tahun Pasifik'. Pada tahun

\footnotetext{
${ }^{3}$ Melanesian Spearhead Group (MSG) adalah salah satu organisasi antarpemerintah di tingkat regional di Pasifik Selatan yang keanggotaannya terdiri dari negara-negara Melanesia, yaitu Fiji, Papua New Guinea, Solomon Islands dan Vanuatu, dan the Kanak and Socialist National Liberation Frontof New Caledonia.Organisasi ini didirikan pada tahun 1983, bermarkas di Port Vila, ibukota Vanuatu.
} 
2011, Menteri Luar Negeri AS, Hillary Clinton, di depan Senat menyatakan, "Let's put aside the moral, humanitarian, do-good side of what we believe in and let's just talk straight, realpolitik. We are in a competition with China". Inggris pun menyatakan kekhawatiran terjadinya persaingan geostrategi di Pasifik setelah kekuatan tradisional mulai meninggalkan wilayah tersebut (Hayward-Jones 2000, 3). Australia merupakan negara yang paling merasa terancam dengan intensitas kehadiran China di Pasifik. Sekali pun tidak secara jelas menyebut China, dokumen resmi pemerintah Australia National Security Strategy tahun 2013 menyebut tentang 'risk of another state seeking to influence Australia or its regional and global partners by economic, political or military pressure' (The Australian Government 2013). Seperti yang pernah disampaikan oleh Perdana Menteri Kevin Rudd, “...there was a danger that China, with its hard-line realist view of international relations, would conclude that an exhausted United States was losing its staying power in the Pacific" (Rudd 2013, 9-15). Pernyataan-pernyataan itu menunjukkan bahwa China mengubah geostrategi di Pasifik Selatan, baik secara nyata maupun perseptual.

Apakah yang menjadi prioritas China di Pasifik Selatan? Pernyataan para elit politik China, baik secara implisit maupun eksplisit mengungkapkan bahwa China tidak memiliki keinginan untuk menjadi hegemon. China belajar banyak dari kegagalan Uni Soviet yang memaksimalkan ambisi militernya sehingga mengorbankan kepentingan domestiknya. China tidak akan mengambil langkah yang sama karena China memberi prioritas pada kesejahteraan rakyat. Selain belajar dari kegagalan Uni Soviet, China belajar banyak dari masa lalunya. Seperti yang dinyatakan di Buku Putih tahun 2005,

During the 100-odd years following the Opium War in 1840, China
suffered humiliation and insult from big powers. And thus, ever
since the advent of modern times, it has become the assiduously
sought goal of the Chinese people to eliminate war, maintain peace,
and build a country of independence and prosperity, and a
comfortable and happy life for the people
(http://www.china.org.cn).

Kekuatan ekonomi China dan kemajuan militernya menimbulkan spekulasi pada kembalinya China dengan ambisi ekspansionisnya seperti yang terjadi dalam sejarah China. Dalam tatanan global saat ini, ambisi tersebut direspon oleh kekuatan global lainnya dengan meningkatkan kewasapadaan masing-masing negara tersebut. Menghadapi situasi yang menjurus kepada rivalitas baru pasca Perang Dingin, para elit China menegaskan bahwa negaranya tidak memiliki ambisi untuk mencari posisi sebagai hegemon karena China memiliki sejumlah persoalan domestik yang perlu diprioritaskan. Pernyataan tersebut bahkan telah disampaikan oleh Deng Xiaoping ada saat China 
menjadi anggota PBB pada tahun 1974. Buku Putih tahun 2005 secara eksplisit menjelaskan,

... China would never seek hegemony. Since the policies of reform and opening-up were introduced, China, keeping in view the changes in the international situation, has upheld the important strategic judgment that peace and development are the theme of the present times, and declared on many occasions that China did not seek hegemony in the past, nor does it now, and will not do so in the future when it gets stronger (http://www.china.org.cn).

Berdasarkan pada pernyataan-pernyataan resmi para elit China, dapat disimpulkan bahwa prioritas China adalah menjadi negara maju. Hal ini hanya dapat terwujud dengan dukungan lingkungan internasional yang damai. Sekali pun demikian, memahami diplomasi China di Pasifik Selatan memerlukan penjelasan lebih jauh.

Menuju abad ke 21, China memproyeksikan diri sebagai kekuatan maritim. Secara geografis, China sangat berkepentingan terhadap Pasifik Selatan sehubungan dengan lokasi geografis Pasifik Selatan yang membentang amat luas dan dikelilingi oleh negara-negara penting di sekitar Samudra Pasifik. China berkepentingan menjalin hubungan kooperatif dengan negara-negara di Pasifik untuk menjamin keamanan maritim, khususnya yang berkaitan dengan keamanan perdagangan yang melewati jalur laut di Pasifik. Pasifik Selatan merupakan target baru bagi ekspansi maritim China. Ambisi maritim China dituangkan dalam Buku Putih Kelautan China yang berjudul China's Ocean Development Report (2012). Selain itu Sekjen Partai Komunis China dan Presiden Hu Jintao pada Kongres partai Komunis China ke 18 pada tahun 2002 menegaskan bahwa, "We should enhance our capacity for exploiting marine resources, develop the marine economy, protect the marine ecological environment, resolutely safeguard China's maritime rights and interests, and build China into a maritime power" (Pidato Presiden $\mathrm{Hu}$ Jintao, 2014).

Untuk mengamankan jalur komunikasi laut (sea lanes of communication-SLOC), seperti membangun jalur laut alternatif di saat krisis dan mendirikan pelabuhan militer dan kunjungan-kunjungan semi militernya. Untuk berbagai keperluan keamanan laut, China juga mengembangkan program satelit pengintai Yuanwang 6 di Suva dan Papeete (Brady 2015). China juga membangun satelit serupa di Kiribati pada tahun 1997. Kapal-kapal nelayan China yang beroperasi di perairan Fiji juga dilengkapi dengan signal pemantau intelijen untuk keperluan pengintaian pada basis militer AS di Mikronesia. China juga berkepentingan atas akses maritim di pelabuhan-pelabuhan negaranegara Pasifik Selatan yang berkaitan dengan zona ekonomi eksklusif, dan memberi program bantuan militer (Wallis 2012). Ekspansi maritim 
China di Pasifik merupakan perwujudan dari strategi "Second Island Chain" yang merupakan manuver global China untuk membangun blue navy project. Strategi Second Island Chain merupakan perpanjangan dari "First Island Chain", yang secara geografis meliputi kepulauan di sekitar Jepang, Taiwan dan Laut China Selatan. Dengan demikian, kepentingan strategik China di Pasifik Selatan berdimensi militer.

Sekali pun demikian, tidak mudah memahami diplomasi China di Pasifik Selatan tanpa melihat problematika hubungan China-Taiwan. Seperti dinyatakan di atas bahwa China bukanlah pemain baru di Pasifik Selatan, namun Pasifik Selatan tidak terlalu menarik bagi China apabila tidak terjadi persaingan diplomatik dengan Taiwan. Persaingan ChinaTaiwan untuk menarik perhatian negara-negara Pasifik diwarnai dengan pemberian bantuan ekonomi dalam berbagai bentuk serta pemberian bantuan keuangan dalam jumlah yang signifikan bagi negara-negara Pasifik (biasa disebut diplomasi dollar). Namun sifat politis dari bantuan itu mendominasi dan membelokkan tujuan utama pemberian bantuan, yaitu mengatasi persoalan kemiskinan dan kesulitan ekonomi negaranegara lemah di Pasifik.

Tujuan persaingan China-Taiwan adalah untuk mendapatkan pengakuan diplomatik, yang seringkali diistilahkan sebagai "chequebook diplomacy". Faktor Taiwan bahkan menjadi determinan sikap China di Pasifik Selatan. Taiwan memiliki hubungan diplomatik dengan Kiribati, Marshall Islands, Nauru, Palau, Tuvalu, Solomon Islands ${ }^{4}$, sementara China memiliki perwakilan diplomatik di Papua New Guinea, Fiji, Samoa, Vanuatu, Kiribati, Tonga and the Federated States of Micronesia, dan mendapat dukungan dari Cook Islands dan Niue. Tidak jarang negara-negara kepulauan tersebut memainkan 'kartu China' demi kepentingan pragmatis mereka. Lebih jauh lagi, persaingan ChinaTaiwan seringkali menyumbang ketidakstabilan politik di kawasan tersebut (Brady, 2015). Kerusuhan di Tonga, Solomon Islands dan Fiji, misalnya, merupakan konsekuensi persaingan China-Taiwan. Persaingan diplomatik keduanya menyebabkan meningkatnya destabilitas di Pasifik, menyebabkan perpolitikan di Pasifik menjadi lebih korup dan violent. Dampak negatif persaingan China-Taiwan iantaranya dapat diamati dari memburuknya hubungan antar-etnis di provinsi Guadalcanal dan Malaita di Solomon Islands (Henderson 2001, 150).

China dan Taiwan telah menyalahgunakan diplomasi dollar sehingga menyebabkan permainan politik di Pasifik menjadi amat berbahaya. Dobell (2007) menyatakan bahwa chequebook diplomacy adalah

\footnotetext{
${ }^{4}$ Selama tahun 1980-2003 Kiribati menjalin hubungan diplomatik dengan China, namun setelah itu berbalik ke Taiwan. Solomon berbalik menjalin hubungan diplomatik dengan China.
} 
praktek membeli pengaruh diplomasi yang berdampak meningkatkan praktek-praktek korupsi sehingga memperparah kondisi yang telah buruk di Pasifik Selatan. Selanjutnya Dobell mengemukakan bahwa China dan Taiwan bersaing secara tidak sehat dan masing-masing menggunakan cara-cara tidak fair di Pasifik Selatan. China dikatakannya telah melakukan 'abusing its prerogatives as a regional leader' dan telah ingkar janji pada prinsip non-intervensi dalam urusan dalam negeri di negara-negara yang menjadi mitra diplomatiknya. Sementara itu, obsesi Taiwan untuk memperoleh keunggulan diplomatik terhadap China menyebabkan negara ini tidak banyak memberi perhatian pada stabilitas Pasifik.

\section{Simpulan}

Walaupun tidak mudah untuk mengambil kesimpulan tunggal mengenai kehadiran China di Pasifik Selatan, dapat diamati bahwa negara ini memiliki potensi untuk menjadi hegemon di Pasifik. Sekalipun China punya banyak kepentingan di kawasan tersebut, menjadi hegemon bisa jadi bukan merupakan proyeksi utama China di kawasan tersebut. Mengamati berbagai pernyataan para pemimpinnya, target utama China di Pasifik dan di berbagai kawasan di dunia adalah mengamankan kepentingan-kepentingan strategisnya tanpa bermaksud menggantikan hegemon yang sudah ada. Tetapi menggunakan perspektif strategic realism yang dirangkai penulis, mengantarkan kita sampai pada titik kesimpulan bahwa apa yang diperlihatkan China melalui kehadirannya di kawasan Pasifik Selatan saat ini lebih merupakan bagian dari strategi global China menyiasati pluralitas global dan menangkap berbagai peluang kepentingan yang dapat dimaksimalkan dari kawasan Pasifik Selatan. Perspektif realisme stratejik menempatkan China pada posisi non-hegemon namun berdimensi multiple recognition yang secara empiris dapat disejajarkan dengan, bahkan dikualifikasikan setara dengan posisi hegemon. Salah satu karakteristik penting realisme stratejik China yang tidak saja ditunjukkannya di kawasan Pasifik, tetapi juga di kawasan lain, adalah dengan kelihaian China menerapkan "Triple A Strategy", yaitu melakukan adaptasi terhadap perbedaan (A1), mengatasi perbedaan (A2), dan mengeksploitasi perbedaan (A3). Dengan kata lain, survival strategy China menghadapi ketatnya persaingannya dengan negara-negara besar lain dan dengan pesaingnya, Taiwan adalah karena China mampu memainkan strategi itu dengan tepat. Sebagaimana terlihat dalam pembahasan, cukup banyak kepentingan yang menjadi taruhan China ketika memutuskan untuk meningkatkan kehadirannya di Pasifik Selatan, sekaligus ingin membuktikan bahwa China hendak meningkatkan hubungan dengan kawasan yang dilihat dari sejarah panjangnya ternyata China telah mempunyai hubungan sejarah dengan wilayah di kawasan ini. 


\section{Daftar Pustaka}

\section{Buku}

Goldstein, A., 2005. Rising to the Challenge: China's Grand Strategy. Stanford: Stanford University Press.

Ghemawat, Pankaj, 2007. Redefining Global Strategy: Crossing Borders in a World here Differences Still Matter. Boston: Harvard Business School Press.

Mearsheimer, John J., 2001. The Tragedy of Great Power Politics. New York: Norton.

\section{E-book}

Husenicová, Lucia. 2012, The China Threat Theory Revisited: Chinese Changing Society and Future Development, In: Majer, M. Ondrejcsák, R. - Tarasovič, V. (eds.): Panorama of global security environment 2012. Bratislava: CENAA, pp. 553-565. http://cenaa.org/analysis/the-china-threat-theory-revisitedchinese-changing-society-and-future-development/ [Diakses 10 April 2015].

\section{Artikel Jurnal}

Waltz, Kenneth. 2000. "Structural Realism after the Cold War". International Security, 25, (1) :5-41.

Bustelo, Pablo. 2005. "China's Emergence: Threat or 'Peaceful Rise'?"Area: Asia-Pacific - ARI No 135/2005 (Diterjemahkan dari bahasa Spanyol). Madrid, Elcano Royal Institute, Madrid's Complutense University

Brady, Anne-Marie. 2008. "New Zealand-China Relations: Common Points and Differences". New Zealand Journal of Asian Studies, 10 (2): $1-20$.

Henderson, John \& Reilly, Benjamin, 2003. "Dragon in Paradise: China's Rising Star in Oceania”. The National Interest, 72: 94-104.

Henderson, John. 2001. "China, Taiwan, and the Changing Strategic Significance of Oceania”. Revue Juridique Polynesienne, 1 (1): 143156.

Hill, Mattew. 2010. "Chessboard of 'Political Bazaar' Revisiting Beijing, Canberra and Wellington's Engagement with the South Pacific". Security Challenges, 6 (3): 41-58.

Keane, John. 2002. "Cosmocracy, A global system of governance or anarchy?”. New Economy, 9 (2): 65-70.

Mearsheimer, John J., 1993. "Back to the Future: Instability in Europe After the Cold War". International Security, 15 (1): 13. 
Rudd, Kevin, 2013. "Beyond the Pivot: A New Road Map for U.S.Chinese Relations". Foreign Affairs, 92 (2): 9-15.

Shie, T. R., 2007. "Rising Chinese influence in the South Pacific". Asian Survey, 47 (2): 307-326.

Yang, Jian, 2009. "China in the South Pacific: hegemon on the horizon?”. Pacific Review, 22 (2): 139-158.

\section{Tesis}

Severson, Jessica Lynn, 2012. Countering the China Threat: China's Goodwill Campaign in Foreign Policy, 2002 - 2012. The University of Oregon.

\section{Artikel Online}

Brady, Marie-Anne, 2015. "China Matters in the South Pacific" [online]. dalam https://www.thechinastory.org/2015/02/china-matters-inthe-south-pacific/ [diakses 13 April 2015].

Chengqiu Wu, 1999. "Barking Up the Wrong Tree? The Master Narrative of "China Threat Theory" Examined [online]. http://www.sirpa.fudan.edu.cn/_upload/article/99/db/oe5d91cd45 aob8fce4e7c74aa2e3/9919d7od-3a97-4eb6-aoc4528abee333b8.pdf. [diakses 25 Maret 2015].

Hayward-Jones, Jenny. 2000. "Big Enough for All of Us: Geo-strategic Competition in the Pacific Islands"[online]. dalam http://www.lowyinstitute.org/publications/big-enough-all-us-geostrategic-competition-pacific-islands [diakses 15 April 2015].

McDonnell, Stephen, 2014. "Gough Whitlam: Prime Minister the Father of Australia-China Relations, Beijing Says" [online]. dalam http://www.abc.net.au/news/2014-10-22/whitlam-father-of-chinaaustralia-relations-beijing/5832076. [diakses 25 April 2015].

Mearsheimer, John. 2004. "Why China's Rise Will Not Be Peaceful" [online]. Dalam http://mearsheimer.uchicago.edu/ pdfs/A0034b.pdf[diakses 18 April 2015].

Wallis, Joanne. 2012. "The Dragon in Our Backyard: the Strategic Consequences of China's Increased Presence in the South Pacific" [online]. dalam http://www.aspistrategist.org.au/the-dragon-inour-backyard-the-strategic-consequences-of-chinas-increasedpresence-in-the-south-pacific/ [diakses 2 April 2015].

Wallis, Joane, 2012. "China's South Pacific Diplomacy" [online]. dalam http://thediplomat.com/2012/o8/chinas-south-pacificdiplomacy/[diakses 23 Maret 2015] 


\section{Working Paper}

Crocombe, Ron, 2007. The Fourth Wave: Chinese in the Pacific Islands in the Twenty-First Century.CSCSD Occasional Paper Number 1, May 2007

Dobell, Graeme. 2007. "China and Taiwan in the South Pacific: Diplomatic Chess versus Pacific Political Rugby”.CSCSD Occasional Paper, No. 1, May 2007.

Hegarty, Matt, 2015. "China's Growing Influence in the South-West Pacific: Australian Policies that could respond to China's intentions and objectives". INDO-PACIFIC STRATEGIC PAPERS. Autralian Defence College, Center for Defence and Strategic Studies.

Lum, Thomas and Bruce Vaughn, 2007. "The Southwest Pacific: U.S. Interests and China's Growing Influence". CSR Report for Congress, July 6.

Wesley-Smith, Terrence, 2007. China in Oceania: New Forces in Pacific Politics. Honolulu, East West Centre.

Willmott, Bill. 2007. The Chinese Communities in the Smaller Countries of the South Pacific: Kiribati, Nauru, Tonga, the Cook Islands. Christchurch: Macmillan Brown Centre for Pacific Studies University of Canterbury.

\section{Speech}

Full text of Hu Jintao's Report at $17^{\text {th }}$ Party Congress, 2007.

http://news.xinhuanet.com/english/2007-

10/24/content_6938749_10.htm. [online] 24 October. [diakses 21

April 2015].

Pidato Presiden Hu Jintao. Full text of Hu Jintao's report at 18th Party Congress, section viii. http://news.xinhuanet.com/english/special/18cpenc/201211/17/c_131981259_9.htm [diakses 28 Februari 2014].

\section{Dokumen resmi}

Australian Government. Department of the Prime Minister and Cabinet, 2013. Strong and Secure: a Strategy for Australia's National Security. Canberra: Commonwealth of Australia.

White Paper on Peaceful Development Road. 2005. [online] dalam http://www.china.org.cn/english/2005/Dec/152669.htm. [diakses 25 April 2015].

China's peaceful rise--A road chosen for rejuvenation of a great nation.

[online] dalam

http://www.chinadaily.com.cn/english/doc/2004-

02/20/content_307915.htm. [diakses 25 April 2015]. 